\title{
Enhancing BWR Proliferation Resistance Fuel with Minor Actinides
}

\section{Plutonium Futures - The Science 2008, A Topical Conference on Plutonium and Actinides}

\author{
Gray S. Chang
}

July 2008

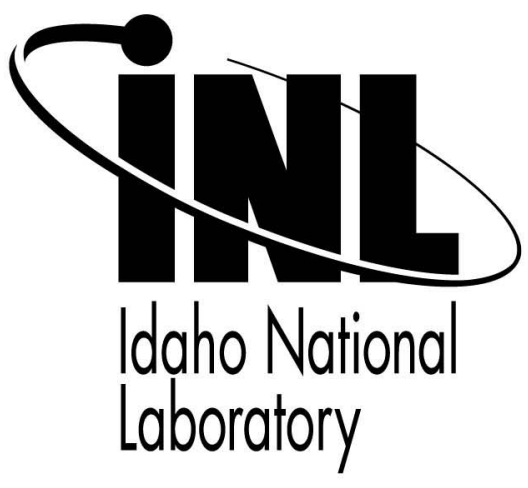

This is a preprint of a paper intended for publication in a journal or proceedings. Since changes may be made before publication, this preprint should not be cited or reproduced without permission of the author. This document was prepared as an account of work sponsored by an agency of the United States Government. Neither the United States Government nor any agency thereof, or any of their employees, makes any warranty, expressed or implied, or assumes any legal liability or responsibility for any third party's use, or the results of such use, of any information, apparatus, product or process disclosed in this report, or represents that its use by such third party would not infringe privately owned rights. The views expressed in this paper are not necessarily those of the United States Government or the sponsoring agency. 


\title{
Enhancing BWR Proliferation Resistance Fuel with Minor Actinides
}

\author{
Gray S. Chang \\ Idaho National Laboratory \\ Idaho Falls, Idaho 83415 USA \\ Tel: (208) 526-7646,Email: gray.chang@inl.gov
}

\begin{abstract}
To reduce spent fuel for storage and enhance the proliferation resistance for the intermediateterm, there are two major approaches (a) increase the discharged spent fuel burnup in the advanced light water reactor- LWR (Gen-III Plus), which not only can reduce the spent fuel for storage, but also increase the ${ }^{238} \mathrm{Pu}$ isotopes ratio to enhance the proliferation resistance, and (b) use of transuranic nuclides ${ }^{237} \mathrm{~Np}$ and $\left.{ }^{241} \mathrm{Am}\right)$ in the high burnup fuel, which can drastically increase the proliferation resistance isotope ratio of ${ }^{238} \mathrm{Pu} / \mathrm{Pu}$.
\end{abstract}

For future advanced nuclear systems, the minor actinides (MA) are viewed more as a resource to be recycled, or transmuted to less hazardous and possibly more useful forms, rather than simply as a waste stream to be disposed of in expensive repository facilities. As a result, MAs play a much larger part in the design of advanced systems and fuel cycles, not only as additional sources of useful energy, but also as direct contributors to the reactivity control of the systems into which they are incorporated. In the study, a typical Boiling Water Reactor (BWR) fuel unit lattice cell model with $\mathrm{UO}_{2}$ fuel pins will be used to investigate the effectiveness of minor actinide reduction approach (MARA) for enhancing proliferation resistance and improving the fuel cycle performance in the intermediate term goal for future nuclear energy systems. To account for the water coolant density variation from the bottom $\left(0.76 \mathrm{~g} / \mathrm{cm}^{3}\right)$ to the top $\left(0.35 \mathrm{~g} / \mathrm{cm}^{3}\right)$ of the core, the axial coolant channel and fuel pin were divided to 24 nodes. The MA transmutation characteristics at different elevations were compared and their impact on neutronics criticality discussed.

We concluded that the concept of MARA, which involves the use of transuranic nuclides ${ }^{237} \mathrm{~Np}$ and/or

$\left.{ }^{241} \mathrm{Am}\right)$, significantly increases the ${ }^{238} \mathrm{Pu} / \mathrm{Pu}$ ratio for proliferation resistance, as well as serves as a burnable absorber to hold-down the initial excess reactivity. It is believed that MARA can play an important role in atoms for peace and the intermediate term of nuclear energy reconnaissance.

KEYWORDS: Plutonium, Minor Actinide, BWR, Proliferation Resistance, Fuel Cycle

\section{INTRODUCTION}

Key aspects of the Global Nuclear Energy Partnership (GNEP) are to significantly advance the science and technology of nuclear energy systems and the Advanced Fuel Cycle (AFC) program. GNEP key elements are: (1) a proliferation-resistant process to separate usable elements in spent nuclear fuel; (2) the reduction of plutonium and minor actinides; and (3) an advanced fuel cycle nuclear system. It consists of both innovative nuclear reactors and innovative research in separation and transmutation.

The challenges are solving the energy needs of the world, protection against nuclear proliferation, the problem of nuclear waste, and the global environmental problem. The merits of nuclear energy are the high-density energy, and low environmental impacts i.e. almost zero greenhouse gas emission. The new deployment of nuclear energy reconnaissance is the key to a secure economy and environment. Nuclear energy is clearly needed for future solutions. To reduce the spent fuel for storage and enhance proliferation resistance for the intermediate-term, there are two major approaches to consider (a) increase the burnup levels to reduce spent fuel for storage, (b) use of transuranic nuclides $\left({ }^{237} \mathrm{~Np}\right.$ and $\left.{ }^{241} \mathrm{Am}\right)$ in high burnup fuel, which can significantly increasing the ${ }^{238} \mathrm{Pu} / \mathrm{Pu}$ ratio and enhancing proliferation resistance.

\section{MINOR ACTINIDES REDUCTION APPROACH IN LWR}

Issues of nuclear waste and proliferation are directly related to the fuel cycle. The overall goal of proliferation resistance is to prevent the extraction of nuclear materials from civilian nuclear power applications that could be used in the production of nuclear weapons. Based on critical mass considerations, the ${ }^{235} \mathrm{U}$ enrichment limit for 
proliferation resistance is $20 \mathrm{wt} \%$. However, unlike uranium, any isotopic mix of plutonium has a finite critical mass, i.e., a potential explosive material. Hence, there is no general isotopic concentration threshold for plutonium isotopes from a critical mass point of view. Nevertheless, the suitability for weapons usage varies significantly for plutonium isotopes. In Ref. 1, lists the important characteristics of plutonium isotopes. ${ }^{238} \mathrm{Pu},{ }^{240} \mathrm{Pu}$, and ${ }^{242} \mathrm{Pu}$ have high spontaneous neutron generation, which reduces the bomb yield significantly. ${ }^{238} \mathrm{Pu}$ also has a high decay heat, which further complicates the design of explosive devices. Consider MARA, where burning minor actinides of ${ }^{237} \mathrm{~Np}$ and/or ${ }^{241} \mathrm{Am}$ in the high burnup fuel can transmute MA which decay to ${ }^{238} \mathrm{Pu}$ in LWRs, which is also the subject of Protected Plutonium Production $\left(\mathrm{P}^{3}\right)$ approach. The subject of $\mathrm{P}^{3}$ approach, which was first proposed by Prof. Saito at Tokyo Tech., Japan, can drastically increase the ${ }^{238} \mathrm{Pu} / \mathrm{Pu}$ ratio and enhance the proliferation resistance through the use of a rather heavy loaded ${ }^{237} \mathrm{~Np}(2 \mathrm{wt} \%){ }^{2}$ However, ${ }^{237} \mathrm{~Np}$ is a controlled nuclear sensitive material. In this study, we use only 0.5 $\mathrm{wt} \%{ }^{237} \mathrm{~Np}$ and $/ \mathrm{or}^{241} \mathrm{Am}$ to achieve proliferation resistance and improve long fuel cycle performance.

For future advanced nuclear systems, the MAs are viewed more as a resource to be recycled, or transmuted to less hazardous and possibly more useful forms, rather than simply as a waste stream to be disposed of in expensive repository facilities. As a result, they play a much larger part in the design of advanced systems and fuel cycles, not only as additional sources of useful energy, but also as direct contributors to the reactivity control of the systems into which they are incorporated. ${ }^{237} \mathrm{~Np}$ and ${ }^{241} \mathrm{Am}$ can be transmuted and decayed to the highly proliferation resistant isotope ${ }^{238} \mathrm{Pu}$.

In the following study, a typical Boiling Water Reactor (BWR) fuel unit lattice cell model with $\mathrm{UO}_{2}$ fuel pins will be used to investigate the effectiveness of MARA for enhancing proliferation resistance and improving the fuel cycle performance in the intermediate term goal for future nuclear energy systems.

\section{BWR UNIT LATTICE CELL MODEL AND MARA STUDY CASES}

A typical BWR (10x10) unit lattice cell, as shown in Fig. 1 , has been chosen as the basis for the fuel neutronics analysis of $\mathrm{UO}_{2}, \mathrm{NpO}_{2}$, and $\mathrm{AmO}_{2}$ with $95 \%$ of theoretical density. The fuel rods have a radius of $0.409 \mathrm{~cm}$ and are clad with $0.063 \mathrm{~cm}$ of $\mathrm{Zr}$. The fuel pins are arranged in a square fuel lattice. The detailed lattice cell parameters are tabulated in Table II. The unique feature of the BWR is that the moderator water density decreases from bottom to top of core. We divided the water coolant channel and fuel pin into 24 axial nodes as shown in Fig. 2. The relative fission power local to average ratio (L2AR) profiles along the 24 fuel nodes at the beginning of life (BOL) and at the end of life (EOL) at the discharged burnup of $53 \mathrm{GWd} / \mathrm{t}$ (see the Results and Discussion section) are shown in Fig. 2.

Increasing the fuel discharge burnup can improve the proliferation resistance and reduce the spent fuel storage volume. In this study, $\mathrm{UO}_{2}$ with ${ }^{235} \mathrm{U}$ enrichment of 4.95 $\mathrm{wt} \%$ was used. For the high burnup fuel with ${ }^{235} \mathrm{U}$ enrichments of $4.95 \mathrm{wt} \%$, three mixed oxide (MO) MA cases for $\mathrm{UO}_{2}+\mathrm{NpO}_{2}, \mathrm{UO}_{2}+\mathrm{AmO}_{2}$, and $\mathrm{UO}_{2}+\mathrm{NpO}_{2}+\mathrm{AmO}_{2}$ were established. The ${ }^{235} \mathrm{U}$ enrichment, $\mathrm{NpO}_{2}$, and $\mathrm{AmO}_{2}$ composition of the 4 study cases are summarized in TableIII.

\section{TABLE II}

BWR (10x10) unit lattice cell parameters.

\begin{tabular}{|l|r|}
\hline Lattice Cell Parameter & Dimension \\
\hline Extend lattice sides tube \& water pitch & $1.85 \mathrm{~cm}$ \\
Lattice pitch & $1.25 \mathrm{~cm}$ \\
Fuel pin outer radius & $0.409 \mathrm{~cm}$ \\
Cladding thickness & $0.063 \mathrm{~cm}$ \\
Effective fuel length & $376 \mathrm{~cm}$ \\
Extend top water and structure & $52 \mathrm{~cm}$ \\
Extend Bottom water and structure & $72 \mathrm{~cm}$ \\
\hline
\end{tabular}

TABLE III

$\mathrm{UO}_{2}-{ }^{235} \mathrm{U}$ enrichment (4.95 wt\%), $\mathrm{NpO}_{2}$, and $\mathrm{AmO}_{2}$ composition of the 4 study cases.

\begin{tabular}{|c|c|c|c|}
\hline ID & $\begin{array}{c}\mathrm{UO}_{2}-{ }^{235} \mathrm{U} \\
\text { enrichment }(\mathrm{wt} \%)\end{array}$ & $\begin{array}{c}\mathrm{NpO}_{2} \\
(\mathrm{wt} \%)\end{array}$ & $\begin{array}{c}\mathrm{AmO}_{2} \\
(\mathrm{wt} \%)\end{array}$ \\
\hline Case-1 & 4.95 & -- & -- \\
\hline Case-2 & 4.95 & 0.5 & -- \\
\hline Case-3 & 4.95 & -- & 0.5 \\
\hline Case-4 & 4.95 & 0.25 & 0.25 \\
\hline
\end{tabular}

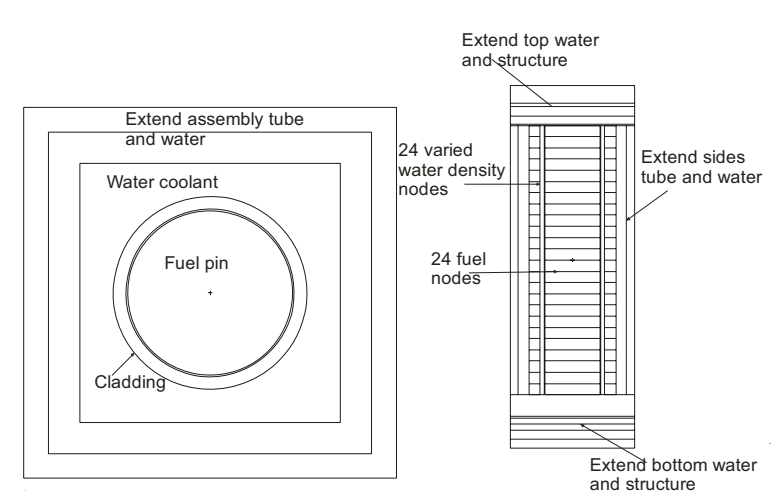

Fig. 1 Typical BWR lattice unit cell model with a fuel pin pitch of $1.25 \mathrm{~cm}$.

\section{MONTE CARLO BURNUP METHOD - MCWO}

The physics analyses were performed using the computer code MCNP. ${ }^{3}$ In addition, the validated fuel 


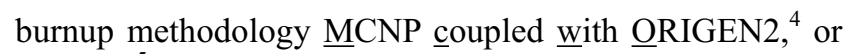
$\mathrm{MCWO},{ }^{5}$ was used. $\mathrm{MCWO}$ has been verified at the Idaho National Laboratory (INL) by benchmarking calculated flux magnitudes with measured flux levels for several experiments and in several test positions of the ATR core. Computer codes MCNP, MCWO, and ORIGEN2 are contained in the INL listing of qualified codes.

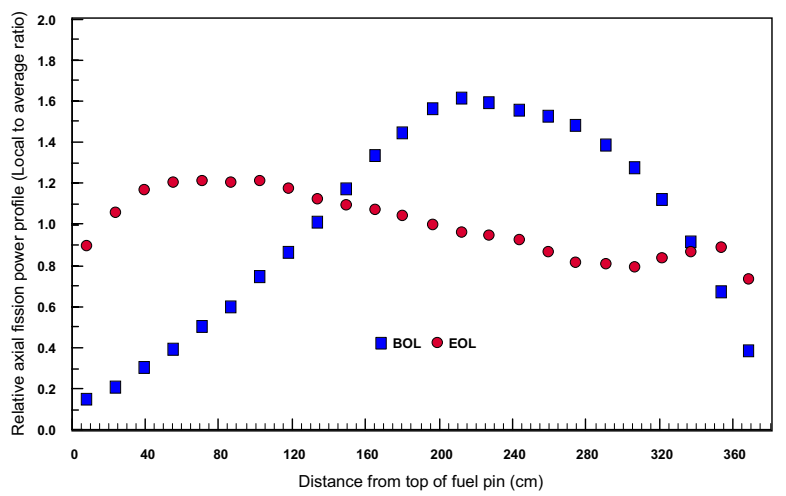

Fig. 2 BWR (10x10) unit lattice, the relative 24 axial nodes fission power profiles at BOL and EOL.

\section{RESULTS AND DISCUSSION}

MCWO-calculated results for all four case studies will be discussed herein. The burnup time interval is 1.25 $\mathrm{GWd} / \mathrm{t}$. For each time step, an MCNP KCODE calculation with 8000 source neutrons for 100 cycles is run, requiring $\sim 15$ minutes of CPU time on a workstation with two dualcore $2.86 \mathrm{GHz}$ XEON processors. The fission tally calculation for each fuel node can achieve a $1 \sigma$ standard deviation of $2 \%$ or less.

The MCWO-calculated K-inf versus burnup for Cases-1 to -4 are plotted in Fig. 3. For K-inf =1.0, Fig. 4 shows that the discharged burnup of all four cases can reach $53 \mathrm{GWd} / \mathrm{t}$. The higher burnup $\mathrm{UO}_{2}$ fuel with ${ }^{235} \mathrm{U}$ $4.95 \mathrm{wt} \%$ can reduce the spent fuel volume proportionally, which benefits the spent fuel storage concerns. From the Fig. 3, it clearly shows that MARA mixed fuel can hold down the initial excess reactivity. The best fuel cycle performance is Case- 3 with $\mathrm{AmO}_{2} 0.5 \mathrm{wt} \%$, which not only can hold down the initial excess reactivity, but also keeps the K-inf to a very desirable flat profile versus burnup. As a result, the ${ }^{241} \mathrm{Am}$ can serve as a burnable absorber to effectively hold down the initial excess reactivity (K-inf) from 1.42 to 1.22 .

One of the criteria in the definition of spent fuel standard, as defined by the National Academy of Sciences ${ }^{6}$ is that the isotopic compositions of the discharged fuel should be about the same as the light water reactor $\mathrm{UO}_{2}$ spent fuel, particularly, the ${ }^{240} \mathrm{Pu} / \mathrm{Pu}$ ratio should be greater than 24\%. The MCWO-calculated (24 nodes averaged) ${ }^{240} \mathrm{Pu} / \mathrm{Pu}$ and ${ }^{238} \mathrm{Pu} / \mathrm{Pu}$ ratio profiles versus burnup are shown in Figs. 4 and 5, respectively. The MCWOcalculated ${ }^{240} \mathrm{Pu} / \mathrm{Pu}$ ratios for Case- 1 at the discharged burnup $(53 \mathrm{GWd} / \mathrm{t})$ can reach about $27 \%$ as shown in Fig. 4. The MCWO-calculated ${ }^{240} \mathrm{Pu} / \mathrm{Pu}$ ratios for Cases-2, -3 , and -4 at the discharged burnup are level-off at $20 \%$, 22 , and $23 \%$, respectively. Although, the ${ }^{240} \mathrm{Pu} / \mathrm{Pu}$ ratios are marginally less than $24 \%$ for Cases- $2,-3$, and -4 , at the discharged burnup, we will discus, that their proliferation resistance ${ }^{238} \mathrm{Pu} / \mathrm{Pu}$ ratios are considerably higher than the Case-1 3\% at the discharged burnup. As a result, the $\left({ }^{238} \mathrm{Pu}+{ }^{240} \mathrm{Pu}\right) / \mathrm{Pu}$ ratios are larger than $24 \%$.

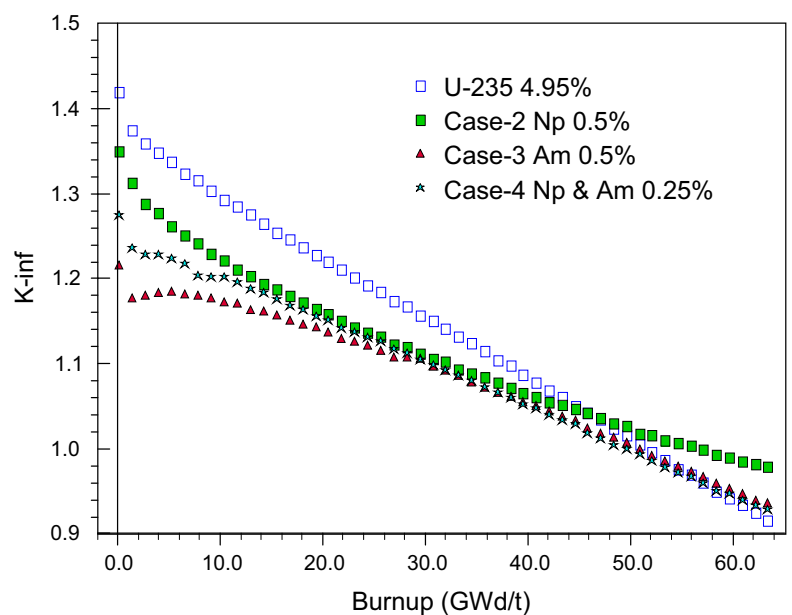

Fig. 3 BWR lattice unit cell MCWO-calculated K-inf versus burnup comparison for Cases- 1 to -4 .

The MCWO-calculated ${ }^{238} \mathrm{Pu} / \mathrm{Pu}$ ratio profiles versus burnup are shown in Fig. 5. Fig. 5 shows that the fraction of ${ }^{238} \mathrm{Pu}$ in the fuel increases with burnup, which can better enhance proliferation resistance. Fig. 6 also shows that the fraction of ${ }^{238} \mathrm{Pu}$ in Case-2 drastically increases to about $17 \%$, then, levels off at $15 \%$, due to the short $\beta$-decay time (2.1-day) for ${ }^{238} \mathrm{~Np}$. For Case-3, the transmutation of the ${ }^{241} \mathrm{Am}$ chain, with the long $\alpha$-decay time of ${ }^{242} \mathrm{Cm}$, causes the fraction of ${ }^{238} \mathrm{Pu}$ to peak at $20 \%$ at a burnup of $22 \mathrm{GWd} / \mathrm{t}$, then, decreases to about $15 \%$. For Case- 4 , the transmutation of the ${ }^{237} \mathrm{~Np}$ and ${ }^{241} \mathrm{Am}$ chain with the long $\alpha$-decay time of ${ }^{242} \mathrm{Cm}$ causes the fraction of ${ }^{238} \mathrm{Pu}$ to reach a peak of $19 \%$ at a burnup of $22 \mathrm{GWd} / \mathrm{t}$, then, decrease to about $16 \%$. In summary, Fig. 5 shows that the fraction of ${ }^{238} \mathrm{Pu}$ of the discharged fuel in Cases-2, -3 , and -4 level off about $15 \%, 15 \%$, and $16 \%$, respectively, which are all higher than the Case-1 of $3 \%$. We conclude that the discharged spent fuel of Cases-3 and -4 can effectively enhance proliferation resistance. The combined fractions of ${ }^{238} \mathrm{Pu}$ and ${ }^{240} \mathrm{Pu}$ can meet the spent fuel standard. In addition, G. Kessler ${ }^{7}$ pointed out that for ${ }^{238} \mathrm{Pu} / \mathrm{Pu}$ above $6 \%$, proliferation resistance can be considered as effective as ${ }^{235} \mathrm{U}<20 \%$ or ${ }^{233} \mathrm{U}<12 \%$.

There is a concern that at the low burnup $(\sim 10 \mathrm{GWd} / \mathrm{t})$ the ${ }^{240} \mathrm{Pu} / \mathrm{Pu}$ ratios are less than $6.5 \%$, which qualify as 
weapons-grade $\mathrm{Pu}$. However, due to the short decay time (2.1-day) from ${ }^{238} \mathrm{~Np}$ to ${ }^{238} \mathrm{Pu}$, MARA can provide a high fraction of ${ }^{238} \mathrm{Pu}$ at the low burnup while providing adequate proliferation resistance.

\section{CONCLUSIONS}

Based on the studies presented herein, it is strongly believed that the concept of MARA, involving the use of transuranic nuclides $\left({ }^{237} \mathrm{~Np}\right.$ and/or $\left.{ }^{241} \mathrm{Am}\right)$, can significantly increase the ${ }^{238} \mathrm{Pu} / \mathrm{Pu}$ ratio for proliferation resistance, as well as serve as a burnable absorber to holddown the initial excess reactivity. It is believed that MARA can play an important role in atoms for peace and the intermediate term of nuclear energy reconnaissance.

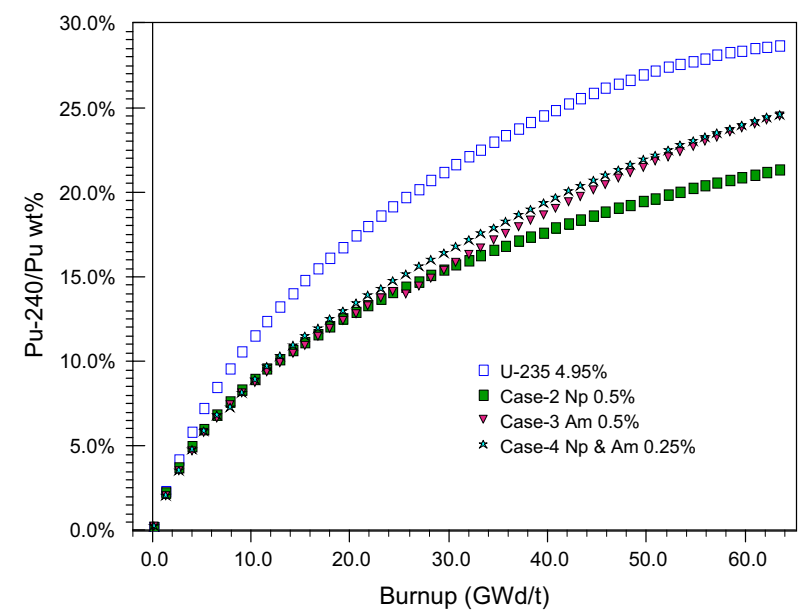

Fig. $4{ }^{240} \mathrm{Pu} / \mathrm{Pu}$ ratio profiles comparison of Cases-1, -2 , and -3 versus burnup.

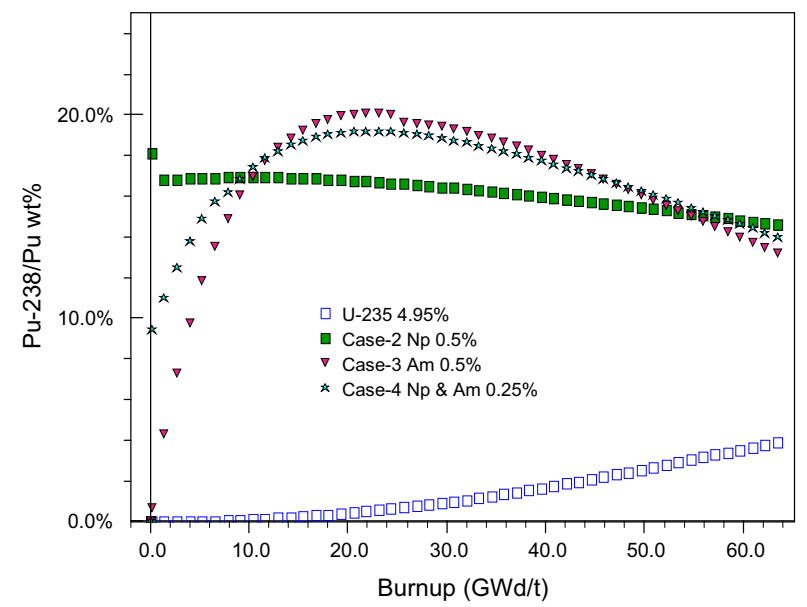

Fig. $5{ }^{238} \mathrm{Pu} / \mathrm{Pu}$ ratio profiles comparison of Cases-1, 2 , and -3 versus burnup.

The known disadvantages of MARA are: (a) ${ }^{237} \mathrm{~Np}$ and ${ }^{241} \mathrm{Am}$ in the fuel will generate more ${ }^{4} \mathrm{He}$, which will affect the fission gas release performance; (b) The need to have improved transuranic cross-section library data; (c)The ${ }^{237} \mathrm{~Np}$ is a controlled nuclear sensitive material.

And, the encouraging advantages of MARA are: (a) The high burnup of the spent fuel $\left({ }^{235} \mathrm{U} 4.95\right.$-wt \%) is well developed and becoming a standard for LWR fuel reloading, which can effectively reduce the spent fuel storage volume; (b) ${ }^{237} \mathrm{~Np}$ and/or ${ }^{241} \mathrm{Am}$ can drastically increase the fraction of ${ }^{238} \mathrm{Pu}$ to enhance the proliferation resistance; (c) ${ }^{241} \mathrm{Am}$ not only can increase the fraction of ${ }^{238} \mathrm{Pu}$, but also can be used as a burnable absorber to reduce the initial excess reactivity; (d) ${ }^{237} \mathrm{~Np}$ can be transmuted quickly with $\beta$-decay (half-life 2.1 days) to a high fraction of ${ }^{238} \mathrm{Pu}$, which can effectively enhance the proliferation resistance for early removal of low burnup fuel.

As a result of the above concerns, it is believed that Case-3 ${ }^{235} \mathrm{U}$ 4.95-wt\% with ${ }^{241} \mathrm{Am} 0.5-\mathrm{wt} \%$ is the best candidate MARA fuel, which not only can achieve the high burnup design goal, but also can achieve the proliferation resistance enhancement goal.

\section{REFERENCES}

1. J. C. Mark, "Explosive Properties of Reactor-Grade Plutonium," Science \& Global Security, 4, 111-128 (1993).

2. M. SAITO, "Advanced Core Concepts with Enhanced Proliferation Resistance by Transmutation of Minor Actinides," Proceedings of GLOBAL 2005 Tsukuba, Japan, Oct 9-13, 2005 Paper No. 172.

3. T. Goorley, J. Bull, F. Brown, et. al., "Release of MCNP5_RSICC_1.30," MCNP Monte Carlo Team X5, LA-UR-04-4519, Los Alamos National Laboratory, November 2004.

4. A. G. Croff, “ORIGEN2: A Versatile Computer Code for Calculating the Nuclide Compositions and Characteristics of Nuclear Materials," Nuclear Technology, Vol. 62, 335-352 (1983).

5. G. S. Chang and J. M. Ryskamp, "Depletion Analysis of Mixed Oxide Fuel Pins in Light Water Reactors and the Advanced Test Reactor," Nucl. Technol., Vol. 129, No. 3, 326-337 (2000).

6. National Academy of Sciences Committee on International Security and Arms, Management and Disposition of Excess Weapons Plutonium, National Academy Press, 1994.

7. G. Kessler, "Plutonium Denaturing by ${ }^{238} \mathrm{Pu}, " \mathrm{Nucl}$. Sci. \& Eng.: 155, 53-73 (2007).

Work supported by the U.S. Department of

Energy, Office of Nuclear Energy, under

DOE-NE Idaho Operations Office

Contract DE-AC07-05ID14517 